\title{
SUSTAINED RELEASE TABLETS OF SORAFENIB-SILIBININ COMBINATIONS FOR THE TREATMENT OF HEPATOCELLULAR CARCINOMA
}

\section{SAVITA MISHRA ${ }^{1 \#, ~ S A N D H Y A ~ H O R A ~}{ }^{1 \#, ~ V I B H A ~ S H U K L A ², ~ M U K U L ~ D A S ~}{ }^{2}$, HARSHA KHARKWAL ${ }^{3}$, DEEPSHIKHA PANDE KATARE*1}

1Proteomics and Translational Research Lab, Centre for Medical Biotechnology, Institute of Biotechnology, Amity University Uttar Pradesh, Noida, India, ${ }^{2}$ CSIR-Indian Institute of Toxicology Research, Lucknow, India, ${ }^{3}$ Amity institute of Phytomedicine and Phytochemistryand Amity Center for Carbohydrate Research, Amity University Uttar Pradesh, Noida, India Email: dpkatare@amity.edu

Received: 29 May 2018 Revised and Accepted: 11 Jul 2018

\section{ABSTRACT}

objective: The aim of this study was to develop polymer coated sustained release tablet using sorafenib and silibinin combination for the treatment of hepatocellular carcinoma.

Methods: The qualitative analysis such as weight variation, friability, hardness, interaction studies, disintegration and in vitro release were performed to validate formulated tablets. We have maintained the acceptable official limits for weight variation, friability, hardness and disintegration time according to prescribed pharmacopoeial recommendation. In vitro drug release studies were performed using USP-II (paddle type) dissolution apparatus. The MTT assay was performed for assessment of Cell viability of drug combination for tablet formulation. Molecular docking studies have been performed to determine the combinatorial mode of action for the tablet formulation.

Results: Friability and weight variation were less than $1 \%$ for each formulation, which were within range of prescribed pharmacopoeial recommendation. The hardness of 20 tablets showed $5-6.5 \mathrm{Kg} / \mathrm{cm}^{2}$ for all formulations $5-6.5 \mathrm{Kg} / \mathrm{cm}^{2}$. The optimized formulation resulted in $98 \%$ drug release after $28 \mathrm{~h}$. The present study reports the synergistic effects of drug combination to inhibit cell growth in HepG2 cell line. Molecular docking studies showed that sorafenib has high binding affinity for B-Raf vascular endothelial growth factor receptor $\beta$ and protein kinase B. Silibinin showed binding affinity with MAP kinase-11, protein phosphatase $2 \mathrm{~A}$ and tankyrase.

Conclusion: The present study reports for the first time a novel formulation for sustained release and reduced toxicity of sorafenib with enhanced inhibitory effect of the drug combination on cancerous hepatic cell line as well collaborative mechanism of action for the formulation.

\section{Keywords: Sustained release, Pullulan, Combinational treatment, Silibinin, Silymarin, Sorafenib, Hepatocellular Carcinoma}

(C) 2018 The Authors. Published by Innovare Academic Sciences Pvt Ltd. This is an open access article under the CC BY license (http://creativecommons.org/licenses/by/4.0/) DOI: http://dx.doi.org/10.22159/ijap.2018v10i5.27597

\section{INTRODUCTION}

Hepatocellular carcinoma (HCC) is a life threatening neoplasm originated from hepatocytes, representing approximately $80 \%$ of liver cancer and $3^{\text {rd }}$ most common cancer related death [1]. HCC is a extremely vascularized and malignant tumor that is responsible for poor survival and rapid recurrence in patients [2, 3]. Sorafenib, an angiogenesis inhibitor is predominantly used as oral drug for HCC treatment [4]. However, long term exposure of sorafenib to the hepatic cells can lead to drug resistance as well as the risk of rebound growth of tumorigenic cells [5]. Combination of natural phytochemicals (silymarin and silibinin) with synthetic (sorafenib) treatment is an alternative way for HCC management, due to their efficacy to protect normal hepatic cell from tumorigenic hepatocytes $[6,7]$. The major issue with this type of infirm soluble drugs is to confront bioavailability and cellular absorption; however, several polymers are prevalent these days to increase bioavailability in the GI tract [8-10]. Polymers such as chitosan, pullulan and cyclodextrin are well established coating material to maintain sustained release of drugs for prolonged therapeutic effect as well as steady drug concentration in blood [11-13]. Pullulan is thermally stable, biodegradable and water soluble compound which consists of stable neutral linear polysaccharide chain of $\alpha-1 ; \alpha-1,6-$ maltotriose monomer [14]. Pullulan has higher affinity to asialo-glycoprotein receptors of hepatic sinusoidal cells and is abundantly expressed in liver. This unique feature of pullulan has been utilized by researchers for targeted drug delivery to the hepatic cells $[15,16]$. Pullulan based prodrugs can enhance the bioavailability of anticancer drugs and improve tumour targeting [17].

The present study reports for the first time pullulan coated matrix tablet having a combination of sorafenib and silymarin/silibinin to target hepatocytes. The tablets were made $\mathrm{pH}$ specific for sustained release into intestinal fluid. The cell viability assay of above combination was performed on Hep G2 cell line to elucidate the effective dose of this formulation to inhibit growth of cancerous hepatic cells. Furthermore, molecular docking of the combination revealedthe collective signalling pathway for both synthetic (sorafenib) and phytoconstituents (silibinin). The formulation is also reducing the toxicity of the synthetic drugs.

\section{METHODS AND MATERIALS}

\section{Chemical required}

Hydroxy propyl methyl cellulose, carboxymethyl cellulose, talc powder, lactose, distilled water, ethanol, isopropyl alcohol, magnesium stearate, croscarmellose sodium Microcrystalline cellulose are procured from Himedia (India). Sorafenib was a gift from Cipla. Dulbecco's Modified essential medium (DMEM) 3-(4, 5dimethyl thiazol-2-yl)-2,5-diphenyl tetrazolium bromide (MTT), and fetal bovine serum (FBS) were purchased from Himedia (India). Trypsin-EDTA (1, 10-phenanthrolinemonohydrate o-phenanthroline ethylene diaminetetraacetic acid), dimethylsulfoxide (DMSO), antibiotic (penicillin-streptomycin solution), silymarin and silibinin are procured from Sigma Aldrich (USA).

\section{Cell culturing}

HepG2 (Human hepatocellular carcinoma) cells were obtained from National Centre for Cell Science (NCCS Pune, Maharashtra, India). The cell culture medium was DMEM supplemented with $10 \%$ heatinactivated fetal bovine serum (FBS), $100 \mathrm{U} / \mathrm{ml}$ penicillin and 100 $\mathrm{g} / \mathrm{ml}$ streptomycin (Invitrogen, Carlsbad, CA). Cells were grown in cell culture media and incubated at $37^{\circ} \mathrm{C}$ in a $5 \% \mathrm{CO}_{2} / 95 \%$ air humidified incubator. For experimental purposes, a fully confluent $75 \mathrm{~cm} 2$ culture flask containing the cells was trypsinized ( $500 \mu \mathrm{l}$ of $0.25 \%$ trypsin). 


\section{MTT assay}

We have performed cell viability assay to investigate the inhibitory effect of sorafenibsilymarin and silibinin individually as well as in combination. The MTT-assay was performed on HepG2 cells using different concentration of drugs and its combinations for determining cell viability [18]. For this, $10 \times 10^{3}$ cells were seeded in 96 well cell culture plates. The cells were incubated with different concentration of silymarin, silibinin and sorafenib alone and its different combination for 24 and $48 \mathrm{~h}$. Each combination contained two types of compounds, one was synthetic (sorafenib) and another was plant based compound either silymarin or silibinin according to the table 1 . After required incubation MTT solution $(5 \mathrm{mg} / \mathrm{ml})$ was added to the each well and further incubates for 2-3 $\mathrm{h}$.

Further, DMSO $(200 \mu \mathrm{l})$ was added to each well for solubilization of fromazon crystals and plate was read at 550 and $660 \mathrm{~nm}$ on a microplate reader (Synergy HT, BIO-TEK International, Winooski, VT). The percentage viability was calculated by comparing the absorbance of control and treated cells.

Table 1: Individual dose and its combination for cell viability assay

\begin{tabular}{ll}
\hline Name of drug & Concentration \\
\hline Sorafenib & $2.5,5,10$ and $20 \mu \mathrm{M}$ \\
Silymarin & $2.5,5,10$ and $20 \mu \mathrm{M}$ \\
Silibinin & $4,10,20,40$ and $80 \mu \mathrm{M}$ \\
Combination1 (Sorafenib: silymarin) & $5: 5 \mu \mathrm{M}$ \\
Combination2 (Sorafenib: silymarin) & $10: 10 \mu \mathrm{M}$ \\
Combination3 (Sorafenib: silibinin) & $10: 20 \mu \mathrm{M}$ \\
Combination4 (Sorafenib: silibinin) & $20: 40 \mu \mathrm{M}$ \\
\hline
\end{tabular}

\section{Drug interaction studies through FTIR}

The drug-drug interaction has been performed using ATR-FTIR (Attenuated total reflection-Fourier transform infrared spectroscopy, Cary 660 FTIR spectrometer-Agilent Technologies) procedure. Sorafenib, silibinin and silymarin individually and in combination (sorafenib-silymarinand sorafenib-silibinin in 1:1 ratio) diluted with chemically latent compound $\mathrm{KBr}$ for pellet preparation. These pellets were scanned from 4000 to 400 em on FTIR for spectra analysis.

\section{Methodology for matrix tablet formulation}

Tablets were formulated using wet granulation method with drugs and excipients. Different concentration of each drug (table 2), lactose 1.2 gram, microcrystalline cellulose 0.8 gram, croscarmellose sodium
$400 \mathrm{mg}$, and magnesium stearate $100 \mathrm{mg}$ were used to prepare 100 tablets. All material except HPMC and talc powder were added in a tray and mixed using double comb blender for 15-20 min. Dough was prepared using minimal amount of 5\% HPMC solution (1-2 ml only). Subsequently, granules were produced using 12 mesh sieve and air dried at $45-50^{\circ}$ for $2 \mathrm{~h}$. These granules were mixed with $100 \mathrm{mg}$ talc powder using double comb blender. Tablets were punched according to their theoretical weight using punching machine.

\section{Pullulan coating}

Coating was done using $2 \%$ pullulan ( $0.05 \%$ glycerol-mili-Q water) solution. Spray coating were done for $3 \mathrm{~min}$ and liquid component of coating material were air dried through passing of air on the tumbling pan for complete dehydration. The multiple cycle of spraying were done for complete coating of the tablets.

Table 2: Concentration of each drug in different formulation

\begin{tabular}{lll}
\hline Name of formulation & Drug concentration per tablet & Theatrical Weight of each tablet \\
\hline Formulation 1 & Sorafenib: Silymarin $(1: 1)(7 \mathrm{mg}+7 \mathrm{mg})$ & $40.0 \mathrm{mg}$ \\
Formulation 2 & Sorafenib: Silibinin $(1: 1)(4.5 \mathrm{mg}+4.5 \mathrm{mg})$ & $36.0 \mathrm{mg}$ \\
Formulation 3 & Sorafenib: Silibinin $(0.7: 1)(3.5 \mathrm{mg}+4.5 \mathrm{mg})$ & $34.5 \mathrm{mg}$ \\
\hline
\end{tabular}

\section{Qualitative evaluation of tablets}

Monsanto hardness tester was used to measure hardness $(n=10)$ of the tablet and unit was Newton/meter. The friability was measured utilizing Roche friabilator and total five tablets were taken from each formulation. First, pre-weighed tablets kept in friabilator for rotation at $25 \mathrm{rpm}$ speed for $4 \mathrm{~min}$ and then reweighed afterremoval. Weight loss percentage was calculated. The disintegration test apparatus was used for disintegration time calculation by keeping one tablet placed in each basket. This procedure has been performed with both acidic medium $(0.1 \mathrm{~N} \mathrm{HCl})$ and basic medium (phosphate buffer $\mathrm{pH}$ 7.4). Disintegration time calculated using stopwatch. Weight variation was carried out to ensure proper amount of drug in each tablet. The test was accomplished after weighing 20 tablets individually using analytical balance and then calculating the average weight.

\section{Dissolution test}

In vitro drug release studies were performed using USP-II (paddle type) dissolution apparatus, on the rotational pace of $50 \mathrm{rpm}$ at $37 \pm 0.5^{\circ}$. Dissolution of formulating tablets was performed under both acidic and basic conditions. $900 \mathrm{ml}$ of $0.1 \mathrm{M} \mathrm{HCl}$ was used for initial $2 \mathrm{~h}$ followed by phosphate buffers ( $\mathrm{pH} 7.4$ ) for $28 \mathrm{~h}$. Sample $(10 \mathrm{ml})$ was withdrawn at specific interims and the same volume of pre-warmed $\left(37 \pm 0.5^{\circ}\right)$ fresh dissolution medium was supplanted to keep up the volume steady. The sample was filtered with Whatman filter paper and different wavelength $(272 \mathrm{~nm}, 288 \mathrm{~nm}$ and $287 \mathrm{~nm}$ for Sorafenib, silymarin and silibinin respectively) were used to calculate the cumulative drug content in each formulation using suitable dilution. The dissolution test was

\section{Molecular docking and metabolic pathway analysis}

An extensive review was performed to identify the effective target proteins for binding of sorafenib and silibinin. Identified proteins were studied for their role in hepatocarcinogenesis. All proteins were directly imported from Protein Data Bank (PDB) into the Protein Preparation Wizard of Maestro9.6 and analyzed for their unordered side chains, loops and missing atoms. Moreover, water atoms were removed and the missing side chains were validated by Prime3.5 program. Protein optimization and minimization was performed for hydrogen atom addition and atomic charge assignment, respectively. Ligands were sketched on 2D-sketcher for structure designing. Later, low energy conformations were achieved for both ligands through ligand preparation (LigPrep2.8 module) in Maestro workspace. Extra Precision (XP) program of Glide6.1 was utilized to dock both ligands with each receptor. The flexible ligand-receptor docking was performed for the conformation generation and only low energy conformations were retained. The Predicted signalling pathway was prepared utilizing glide score of ligand receptor docking.

\section{Statistical analysis}

The results were studied using either one way or two ways ANOVA (analysis of variance) and p-value $<0.05$ was measured to be statistically significant using Graph Pad Prism software, U. S. A. 


\section{RESULTS}

Effect of individual dose of sorafenib, silymarin and silibinin on HepG2 cell line

Dose and time dependent effects of sorafenib, silymarin and silibinin were determined at different concentrations $(2.5,5,10,20$ and 40 $\mu \mathrm{M}$ ) in HepG2 cells by performing MTT assay. As shown in fig. 1. All the three compounds did not exhibit any significant effect at $24 \mathrm{~h}$.
However at $48 \mathrm{~h}$, cell viability was significantly reduced to $87 \%$, $88 \%, 74 \%$ and $67 \%(\mathrm{P}<0.001)$ at $5-40 \mu \mathrm{M}$ concentration of sorafenib. Further, plant based compound, Silymarin also showed significant effect at $48 \mathrm{hr}$ showing reduced cell viability from $78 \%$ to $67 \%(\mathrm{P}<0.001)$ at concentrations of $5-40 \mu \mathrm{M}$. Similar trend was exhibited by another plant based compound, Silibinin that reduced the cell viability by $84 \%, 75 \%, 66 \%, 71 \%$, and $65 \%(\mathrm{P}<0.001)$ at 48 $\mathrm{h}$ incubation with $2.5-40 \mu \mathrm{M}$ concentration.
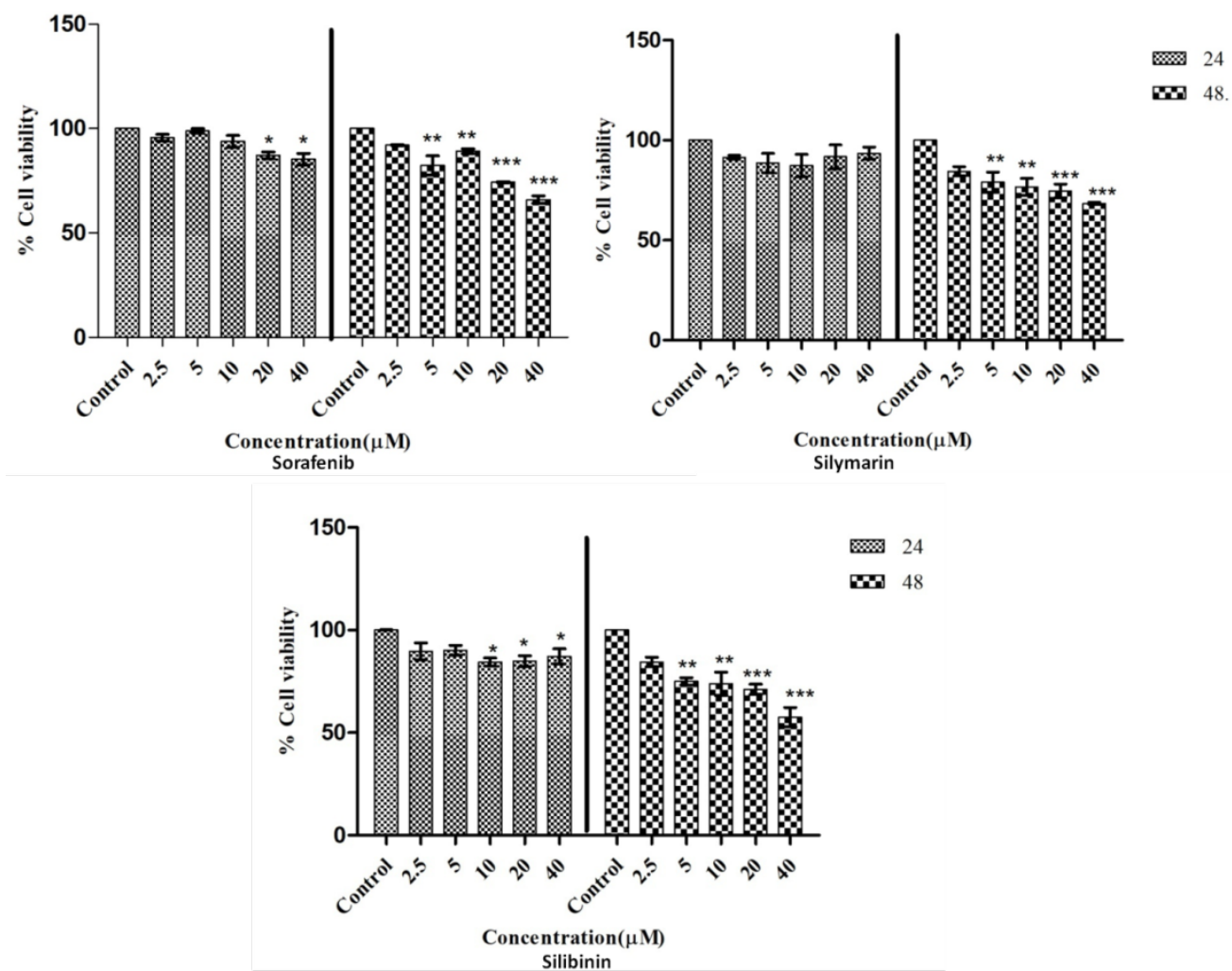

Fig. 1: Percent viability of Hep G2 cell line after individual drugs exposure, $\left(\mathrm{n}=5\right.$; mean+SD; ${ }^{*}<0.05 ;{ }^{* *}<0.01$; and ${ }^{* * *}<0.001$ as compared to control cells)

\section{Formulation of tablets and evaluation of their efficacy}

\section{Drug-drug interaction studies}

IR spectra of each drug and combination (sorafenib with silymarin/silibinin) component were carried out for drug-drug interaction analysis (fig. $2 \mathrm{~A}$ and 2 B). No major differences in the FTIR. patterns of pure drug and combination were observed.

The FTIR studies confirmed that there is no interaction between synthetic and phytochemical drug in the tablets of combination drug.

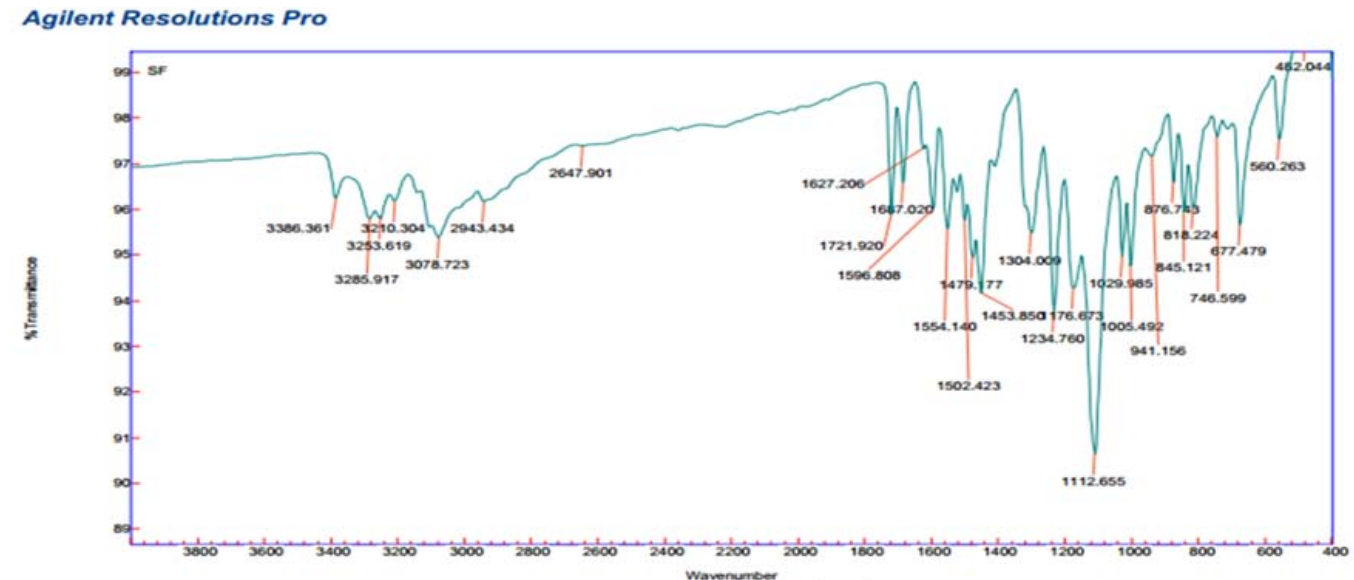



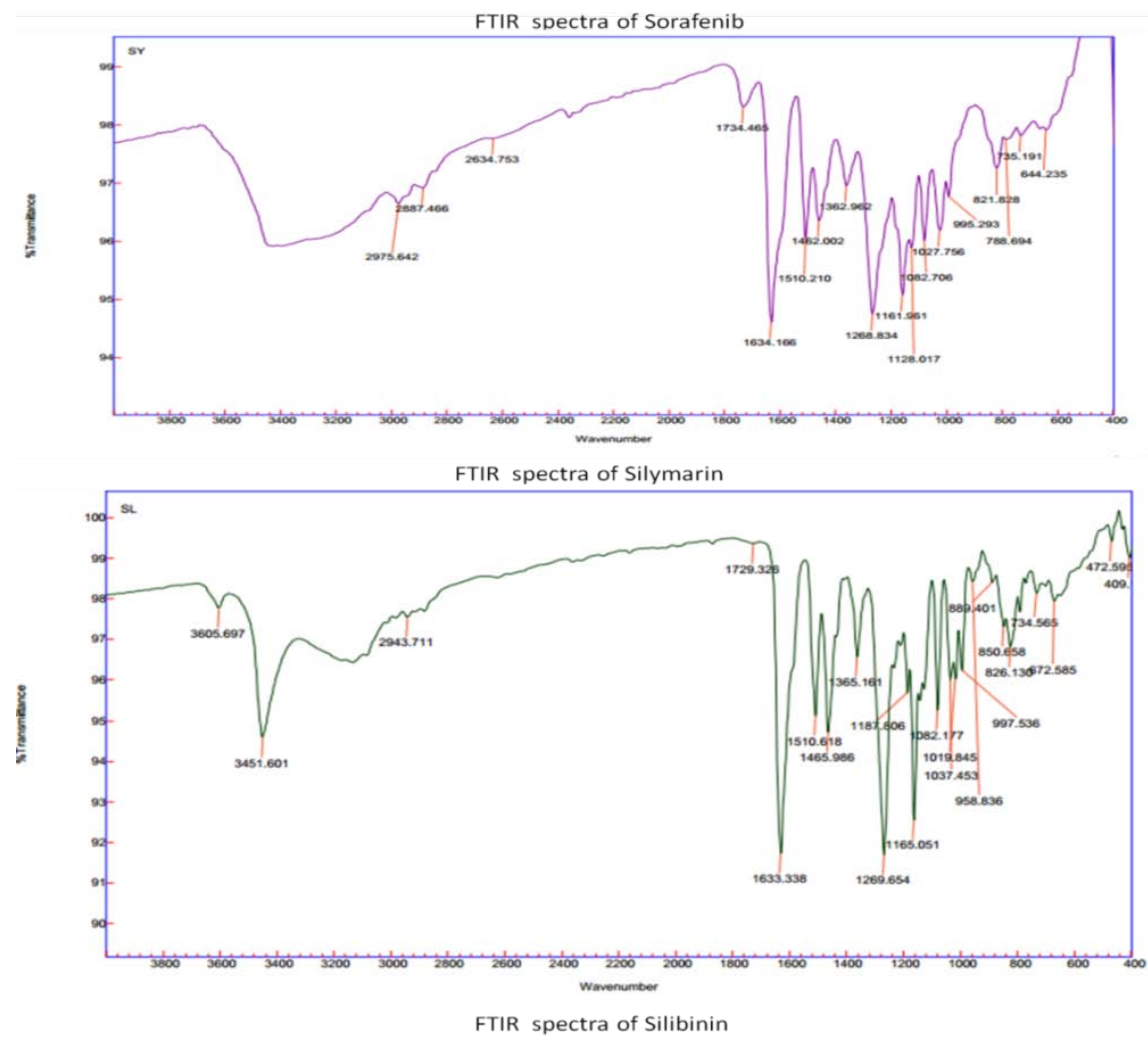

Fig. 2A: FTIR spectra of individual drugs (Sorafenib, Silymarin and Silibinin)

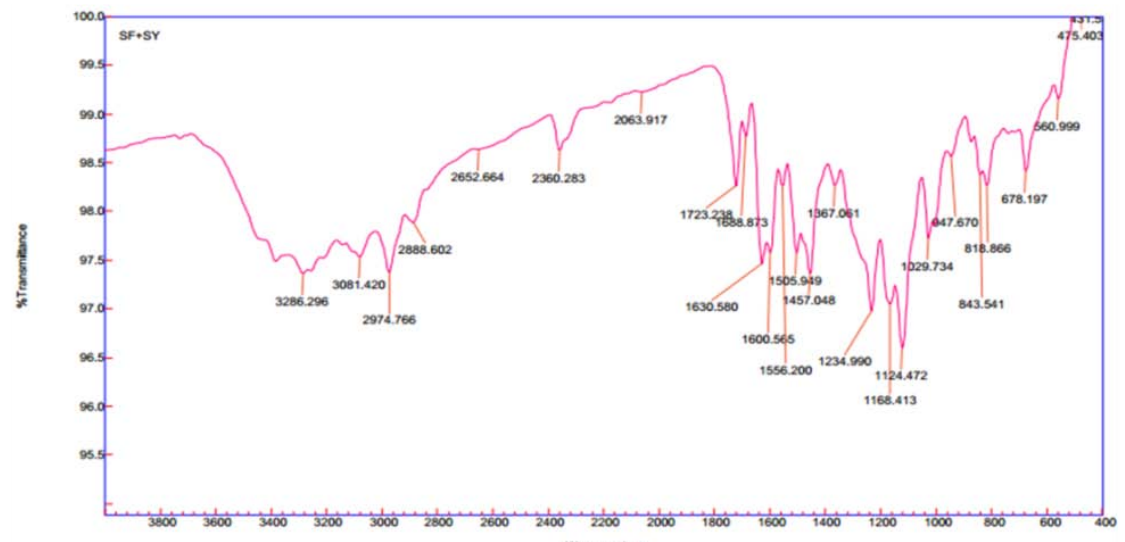

FTIR spectra of Sorafenib and silymarin

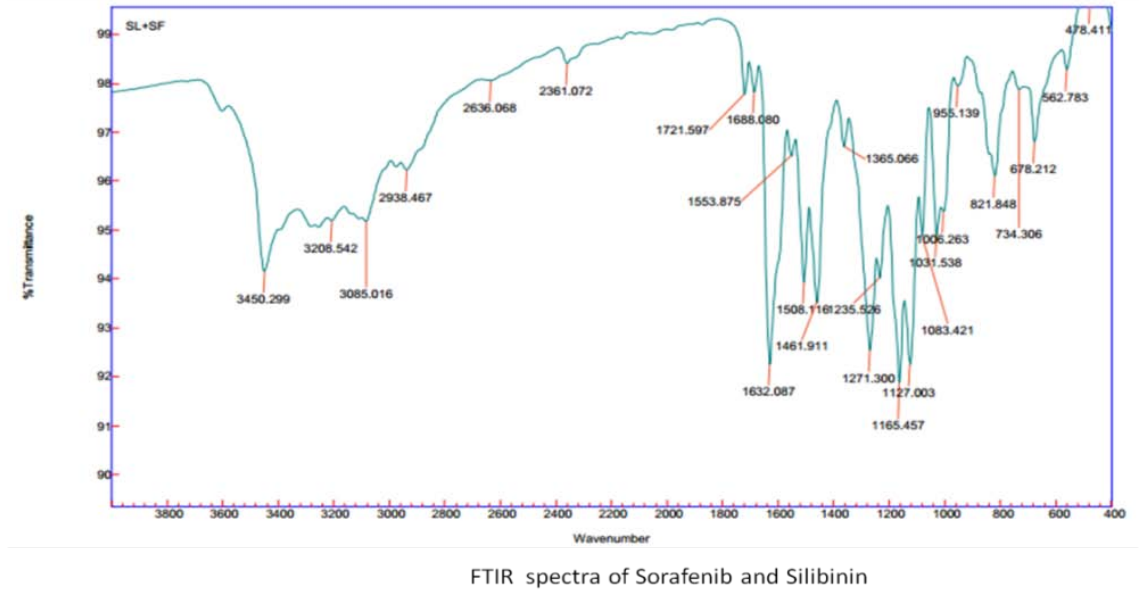

Fig. 2B: FTIR spectra of combination (Sorafenib: Silymarin and Sorafenib: Silibinin) 


\section{Qualitative analysis}

We formulated three types of pullulan coated tablets, sorafenib in combination with silymarin and/or silibinin in 1:1 ratio and sorafenib with silibinin in $0.7: 1$ ratio. Small variation in the qualitative study of each formulation (F1, F2 and F3) was indicative of uniform compression procedure throughout tablet formulation. All formulations were prepared utilizing $1-3 \%$ of pullulan coating. however, the best result of coating was found with $2 \%$ of pullulan in
$0.05 \%$ glycerol solution (Significant batch of each formulation has been illustrated). Different qualitative parameters including hardness, friability and weight variety of formulated matrix tablets were analysed to identify the best combination of pullulan coated synthetic and herbal drugs. Friability and weight variation were less than $1 \%$ for each formulation, which were within range of prescribed pharmacopoeial recommendation. The hardness of 20 tablets showed $5-6.5 \mathrm{Kg} / \mathrm{cm} 2$ for all formulations which was within the acceptable official limits (table 3, fig. 3).

Table 3: Quality control test result: the table shows quality control results of formulated tablets for each combination

\begin{tabular}{|c|c|c|c|c|c|}
\hline $\begin{array}{l}\text { Formulation } \\
\text { numbers }\end{array}$ & $\begin{array}{l}\text { Friability \% } \\
(n=5 ; \text { mean+SD) }\end{array}$ & $\begin{array}{l}\text { Hardness } \mathrm{Kg} / \mathrm{cm} 2 \\
\text { average }(\mathrm{n}=20 \text {; } \\
\text { mean+SD) }\end{array}$ & $\begin{array}{l}\text { Weight variation \% } \\
(n=10 ; \text { mean+SD) }\end{array}$ & $\begin{array}{l}\text { Disintegration } \\
\text { time in } 0.1 \mathrm{~N} \mathrm{HCl}\end{array}$ & $\begin{array}{l}\text { Disintegration } \\
\text { time in phosphate } \\
\text { buffer }\end{array}$ \\
\hline formulation 1 (F1) & $0.53 \pm 0.001$ & $5 \pm 0.09$ & $44.16 \pm 0.29$ & No Disintegration & $30 \mathrm{~min}$ \\
\hline formulation 2 (F2) & $0.41 \pm 0.012$ & $6.5 \pm 0.08$ & $36.58 \pm 0.41$ & No Disintegration & $20 \mathrm{~min}$ \\
\hline formulation 3 (F3) & $0.43 \pm 0.001$ & $6.2 \pm 0.019$ & $37.66 \pm 0.27$ & No Disintegration & $15 \mathrm{~min}$ \\
\hline
\end{tabular}

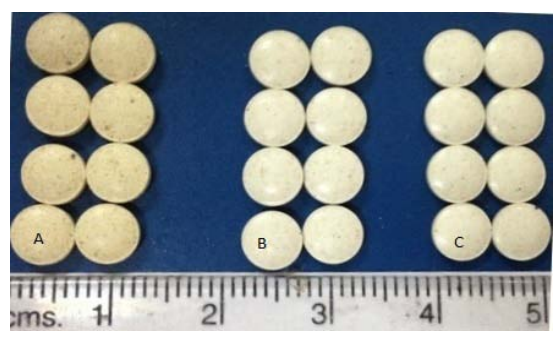

Fig. 3: Combination tablets A) formulation 1; B) Formulation 2; C) Formulation 3

\section{Disintegration analysis}

The enteric coating capability of pullulan made the tablets unable to disintegrate in $0.1 \mathrm{~N} \mathrm{HCl}$. Five tablets were kept in $0.1 \mathrm{~N} \mathrm{HCl}$ for $2 \mathrm{~h}$, but no disintegration reported throughout duration. However, when the medium was changed with phosphate buffer it took $(\mathrm{pH} 7.4) 30$, 20 and $15 \mathrm{~min}$ to disintegrate formulation 1 , formulation 2 and formulation 3 respectively (table 3 ).

\section{Dissolution studies}

Enteric coating pullulan did not show any release in $0.1 \mathrm{~N} \mathrm{HCl}$ within $2 \mathrm{~h}$ in each formulation. The dissolution medium was changed with phosphate buffer and the drug release was observed. In formulation 1 sorafenib released up to $67 \%$ whereas in same formulation silymarin has released up to $90 \%$. Formulation 2 showed release of $98 \%$ for both sorafenib and silibinin. On the other hand, formulation 3 showed moderate release of both drugs that was $73 \%$ and $84 \%$ for sorafenib and silibinin, respectively. The $P$ value was less than 0.001 for each formulation showed its significance. Due to controlled release medium each formulation has taken minimum $28 \mathrm{hr}$ to release its maximum amount (fig. 4)
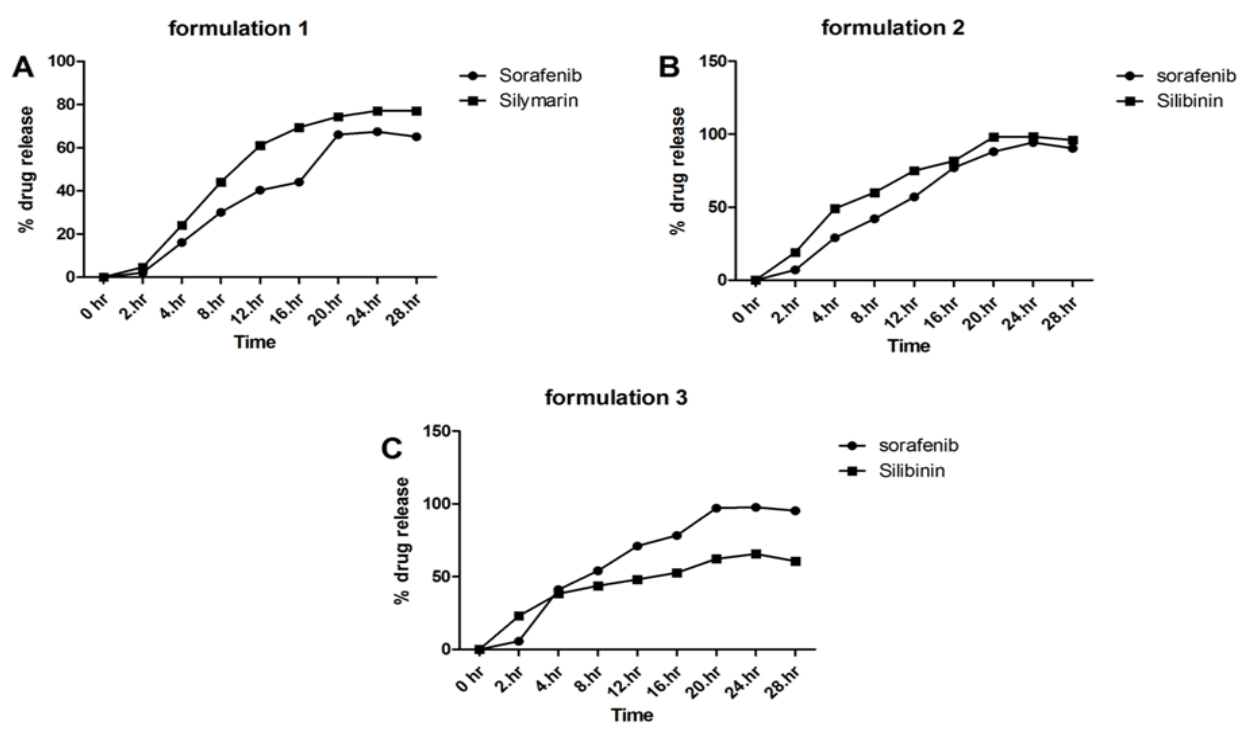

Fig. 4: Percent drug release of individual drugs in each formulation ( $n=5$; mean+SD)

\section{Effect of combinational treatment on HepG2 Cell lines}

For evaluation of the combinational effect of synthetic and herbal drug, different drug formulations were prepared. HepG2 cells were treated with combination 1 (Sorafenib: silymarin 5: $5 \mu \mathrm{M}$ ) showed reduced cell viability by $77 \%$ and $62 \%(\mathrm{P}<0.01)$ at 24 and $48 \mathrm{~h}$ of incubation. Whereas combination 2 (Sorafenib: silymarin 10: $10 \mu \mathrm{M}$ ) showed to be more effective than the combination 1 and the cell viability reduced to
$61 \%$ and $54 \%(\mathrm{P}<0.001)$ at same time points. Combination 3 (Sorafenib: silibinin 10: $20 \mu \mathrm{M}$ ) and Combination 4 (Sorafenib: silibinin $20: 40 \mu \mathrm{M})$ reduced cell viability by $61 \%$ and $51 \%(\mathrm{P}<0.001)$ at $24 \mathrm{~h}$, whereas at $48 \mathrm{~h}$ it found to be more effective and reduced cell viability by $52 \%$ and $45 \%(\mathrm{P}<0.001)$, respectively. From the above results it is clear that combination 4 showed better cytotoxic effects against hepatocellular carcinoma cells in comparison to the individual compounds or other combinations (fig. 5). 


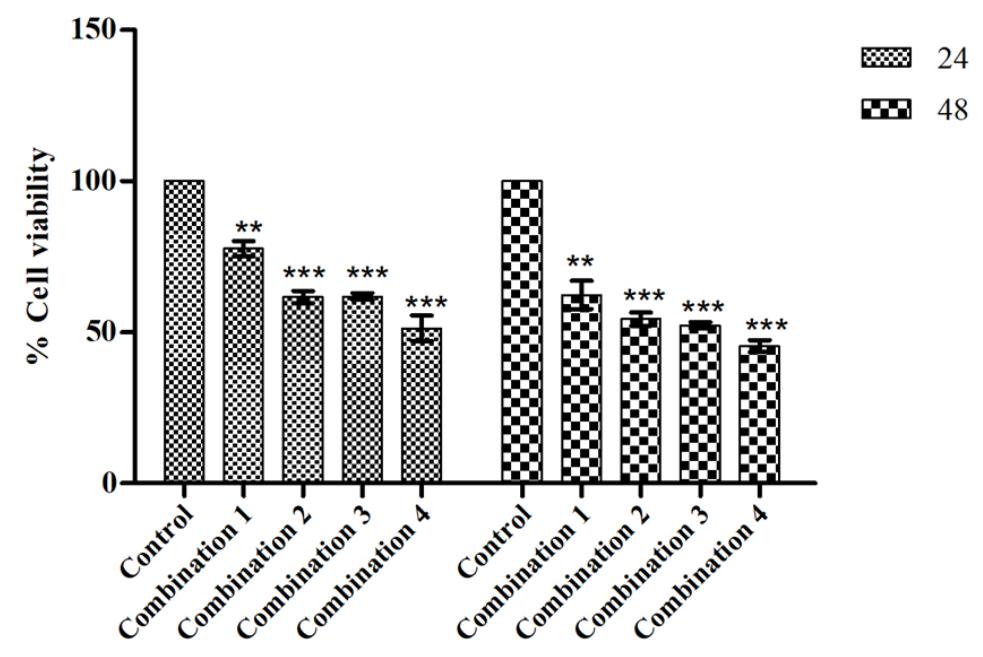

Treatment

Fig. 5: Percent viability of Hep G2 cell line after combination of drugs exposure, $\left(\mathrm{n}=5\right.$; mean+SD; ${ }^{* *} \mathrm{P}<0.01$ and ${ }^{* * *} \mathrm{P}<0.001$ as compared to control cells)

\section{Molecular docking analysis}

We have retrieved the target proteins involved in hepatocarcinogenesis through extensive literature survey. Molecular docking helped us to understand and analyze the binding efficacy between ligands and receptors. Different poses of ligands were allowed to dock with each receptor and were reviewed according to their Glide Score. Sorafenib has high binding affinity for B-Raf ($12.804)$, vascular endothelial growth factor receptor $\beta$ (VEGFR- $\beta$ ) ($12.651)$ and protein kinase B (AKT) $(-8.488)$ which provided an antagonist for inhibition of angiogenesis and cell proliferation [Table 4; fig. 6; Supplementary file]. Silibinin showed binding affinity with number of receptors such as MAP kinase-11 (p38) (-11.471), protein phosphatase 2 A (PP2A) (-6.781), tankyrase (-11.221) and predicted as inhibitor of cell proliferation, survival and differentiation [Table 4; fig. 6; Supplementary file]. However, both ligands have shown good binding affinity with epidermal growth factor receptor 1 (EGFR-1), fibroblast growth factor receptor (FRFR-1) and hepatocyte growth factor receptor (c-Met) that showed inhibited cell proliferation and survival through antagonist binding. Therefore, overall docking score of sorafenib/silibinin with respective protein hypothesized a collaborative signalling pathway through inhibition of Ras/Raf/MEK/ERK, PI3K/AKT/mTOR, Wnt/ $\beta$-catenin routes for treatment of HCC [fig. 7].
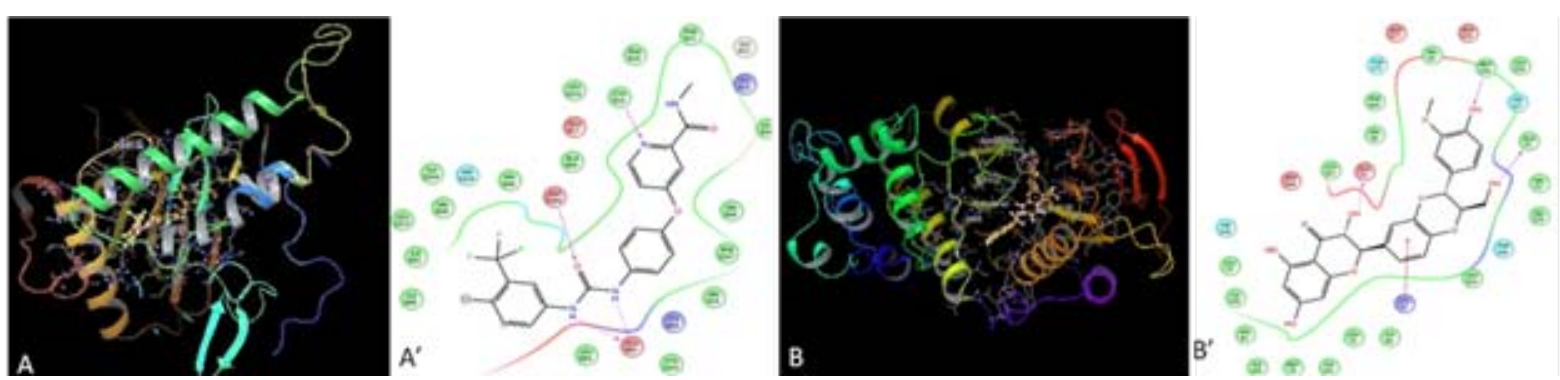

Fig. 6: Docking poses of (A and A') Sorafenib with VEGFR- $\beta$ (vascular endothelial growth factor receptor $\beta$ ) and (B and B') Silibinin with p38 (Mitogen-activated protein kinase 11)

Table 4: Docking score of both ligands with different receptors

\begin{tabular}{lll}
\hline Name of receptor (PDB ID) & Glide score with sorafenib & Glide score with silibinin \\
\hline VEGFR2 (4ASD) & -12.651 & -8.395 \\
B-Raf (5HI2) & -12.804 & -9.466 \\
AKT (3CQU) & -8.488 & -6.911 \\
FGFR1 (5B7V) & -9.034 & -8.659 \\
EGFR(5HCX) & -8.144 & -8.837 \\
HGFR (5HLW) & -7.705 & -9.116 \\
MAPK11 (3HEC) & -9.625 & 11.471 \\
Tankyrase (5FPF) & -10.870 & -11.221 \\
PP2A (3K7V) & -4.336 & -6.781 \\
\hline
\end{tabular}

The glide score<-7.00 represents permissible affinity of particular drag to their receptor and can act as antagonist to respective protein (vascular endothelial growth factor receptor (VEGFR- $\beta$ ); protooncogene B-Raf (B-Raf); protein kinase B-1(AKT-1); Fibroblast growth factor receptor 1(FGFR1); epidermal growth factor receptor (EGFR); hepatocyte growth factor receptor (HGFR); Mitogenactivated protein kinase 11 (p38); tankyrase; protein phosphatase 2 A (PP2A)) 


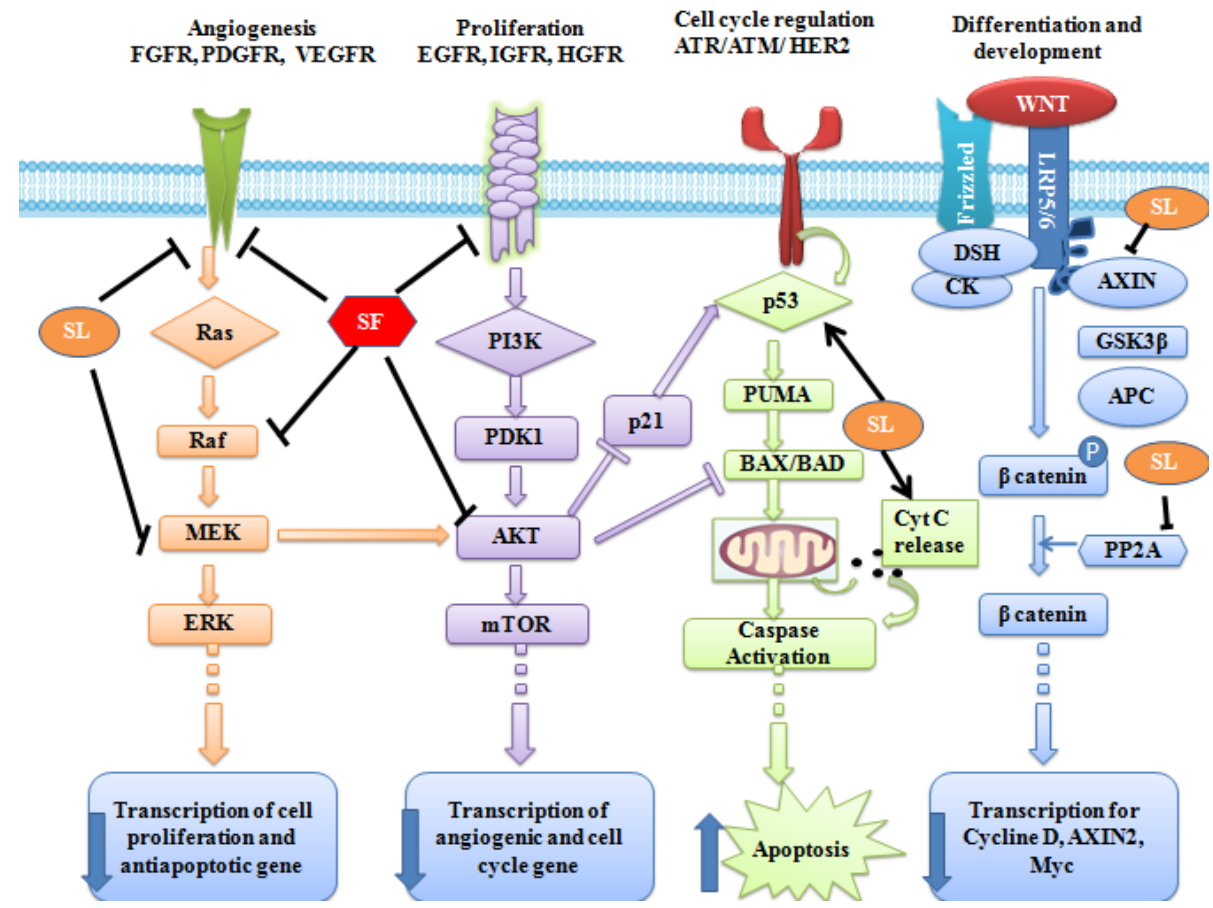

Fig. 7: The target proteins which are involved in hepatocarcinogenesis can be inhibited by sorafenib (SF) and silibinin (SL). Sorafenib has antagonist effect of vascular endothelial growth factor receptor (VEGFR- $\beta$ ), proto-oncogene B-Raf and protein kinase B-1(AKT-1). However, silibinin is involved in inhibition of mitogen-activated protein kinases (p38), AKT, Protein kinase B, tankyrase and protein phosphatase 2 A (PP2A). MEK kinases (MEK); extracellular signal-regulated kinase (ERK); phosphatidylinositol-3-kinase (PI3K); Insulinlike growth factor receptor (IGFR); Pyruvate dehydrogenase lipoamide kinase isozyme 1 (PDK1); Mammalian target of rapamycin (mTOR); Tumor protein p53 (Tp53); p53 unregulated modulator of apoptosis protein (PUMA); BCL-2-associated death promoter (BAD); a family of G-protein-coupled receptor proteins for WNT/ $\beta$-catenin signalling pathway (Frizzled); Low-density lipoprotein receptor-related

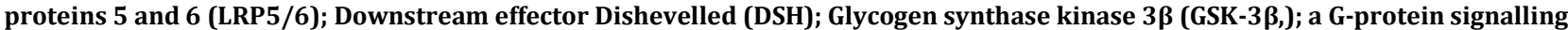
molecule (AXIN); Casein kinase (CK); Adenomatous polyposis coli (APC)

\section{DISCUSSION}

The study successfully develops sustained release pullulan-coated tablets containing sorafenib in combination with silymarin and silibinin. Silymarin and its major constituent silibinin have hepatoprotective and cytotoxic nature against cancerous hepatic cells $[19,20]$. Our previous report on combinational formulation also suggested that plant based compound with synthetic drugs are more effective and less toxic for HCC treatment [21]. Interestingly, Silibinin and sorafenib follow same pathways to inhibit cell growth [22]. Taking this phenomenon into consideration, we have used silymarin and its major constituent silibinin in combination with sorafenib for tablet formulation. Pullulan coated enteric tablets were prepared for sustained release of drugs in intestinal tract. The enhanced solubility of drug is expected in intestinal fluids with shift of dissolution medium from acidic to basic phase [9,23]. Our results are in accordance with the earlier reports and as we have observed that after changing the $\mathrm{pH}$ of dissolution medium from $0.1 \mathrm{~N} \mathrm{HCl}$ to phosphate buffer ( $\mathrm{pH}$ 7.4) enhanced release of drug/s were obtained. This is the first report of a novel formulation using synthetic and herbal drug in sustained release for the treatment of HCC. The physical parameters of each formulation such as average weight, hardness, friability and disintegration capacity of tablets were within the permissible range and assured the formulation quality. Moreover, dissolution of each drug started in a controlled manner and maximum release occurred within $28 \mathrm{~h}$, which represented the sustained release of both drugs at specific $\mathrm{pH}$ as a result of pullulan coating. Similarly, the $\mathrm{pH}$ specific controlled release of drugs through pullulan or other biopolymers have been earlier reported by researchers to maintain plasma concentration for longer duration [11, 24]. Our dissolution studies demonstrated that formulation 2, (sorafenib with silibinin in 1:1 ratio) showed maximum release up to $98 \%$ for both drugs after $28 \mathrm{~h}$. However, it was quite lower in formulation $3(73 \%$ and 84 for sorafenib and silibinin, respectively). The lowest release of sorafenib was observed in presence of silymarin in formulation $1(67 \%$ and $90 \%$ for sorafenib and silymarin, respectively). This observation gave an idea that instead of silymarin complex, silibinin can be used as a better option for combination treatment. However, not much work has been done on the combination of sorafenib and silibinin as for today. A study conducted by $\mathrm{Gu}$ and coworkers reported that silibinin in combination with sorafenib/gefitinib inhibits growth of cancerous cell lines, but their work mainly emphasize on the efficacy of silibinin-gefitinib combination. [25]. Our result strengthens the idea that sorafenib in combination with silibinin have synergestic effect on HCC cell line. The maximum growth inhibition effect of each drug was seen at its higher concentration $(40 \mu \mathrm{M}$ and $80 \mu \mathrm{M}$ for sorafenib/silymarin and silibinin, respectively). However, in combination, $20 \mu \mathrm{M}$ of silibinin with $10 \mu \mathrm{M}$ sorafenib was enough to reduce cell viability up to $59 \%$ after 24 hour incubation. The overall cell viability assay affirmed that sorafenib and silymarin has cytotoxicity against tumorigenic hepatic cells, whereas combination of sorafenib and silibinin showed synergistic growth inhibition of cancer-bearing hepatocytes with maximum sustained release.

The molecular docking studies were performed to elucidate signalling pathways affected by combinatorial formulations. The docking studies can be considered as an emerging tool in discovery of new targets $[26,27]$. We have observed that sorafenib and silibinin inhibit their specific pathways along with other signalling routes which are involved in hepatocarcinogenesis. The result showed that sorafenib was inhibiting angiogenesis and cell proliferation through binding with VEGFR- $\beta$, B-Raf and Protein kinase $B$. Whereas, silibinin acted as antagonist for wnt/ $\beta$-catenin pathway through inhibition of AXIN1 activation (binding with tankyrase) and $\beta$-catenin dephosphorylation (binding with PP2A) $[28,29]$. Moreover, silibinin can also inhibit cell survival through antagonist binding of c-Met and MAP Kinase-11(p38). Sorafenib and silibinin have antagonist binding with EGFR1 and FGFR1 for inhibition of cell proliferation and angiogenesis, respectively. The 
studies by other researchers have also shown similar inhibitory effects on various cancerous cell-lines after incubation with both drugs individually [22, 30,31]. The overall pathway deciphers the collaborative signalling for inhibition of tumorigenesis through down regulation of cell proliferation, angiogenesis and cell survival.

\section{CONCLUSION}

Polymer coated tablet formulations are efficient and established methods to accomplish sustained release of drugs. Pullulan, a thermally stable and neutral linear polysaccharide, is an amazing polymer for sustain release and liver targeting. The present study concludes that pullulan coated tablet has the ability to maintain steady drug concentration in blood. Sorafenib and silibinin combination can assure the sustained release of both drugs and an effective combination for the treatment of hepatocellular carcinoma through inhibition of cell survival, proliferation and differentiation. However, preclinical studies are required for further analysis.

\section{ACKNOWLEDGEMENT}

Authors would like to thank Dr. Ashok K. Chauhan, Founder President, Amity University Uttar Pradesh, Noida, India for providing the infrastructure and support. We acknowledge Cipla Ltd for providing sorafenib.

\section{AUTHORS CONTRIBUTIONS}

All the author have contributed equally

\section{CONFLICT OF INTERESTS}

Declared none

\section{REFERENCES}

1. Zhu RX, Seto WK, Lai CL, Yuen MF. Epidemiology of hepatocellular carcinoma in the asia-pacific region. Gut Liver 2016;10:332.

2. Yang $\mathrm{X}$, Zhang $\mathrm{XF}, \mathrm{Lu} \mathrm{X}$, Jia HL, Liang L, Dong QZ, et al. MicroRNA-26a suppresses angiogenesis in human hepatocellular carcinoma by targeting hepatocyte growth factor-cMet pathway. Hepatology 2014;59:1874-85.

3. Malik S, Bhatnagar S, Chaudhary N, Katare DP, Jain S. DEN+2AAF-induced multistep hepatotumorigenesis in Wistar rats: supportive evidence and insights. Protoplasma 2013;250:175-83.

4. Qun W, Tao Y, Yi D, Weijun L, Fu W. Effective personalized treatment of advanced hepatic carcinoma based on sorafenib. J Integr Oncol 2016;5:2.

5. Van Malenstein H, Dekervel J, Verslype C, Van Cutsem E, Windmolders P, Nevens F, et al. Long-term exposure to sorafenib of liver cancer cells induces resistance with epithelial-to-mesenchymal transition, increased invasion and risk of rebound growth. Cancer Lett 2013;329:74-83.

6. Hellerbrand C, Schattenberg JM, Peterburs P, Lechner A, Brignoli R. The potential of silymarin for the treatment of hepatic disorders. Clin Phytosci 2016;2:1.

7. Lu K, Bhat M, Basu S. Plants and their active compounds: natural molecules to target angiogenesis. Angiogenesis 2016;19:287-95.

8. Zhang Z, Niu B, Chen J, He X, Bao X, Zhu J, et al. The use of lipidcoated nanodiamond to improve bioavailability and efficacy of sorafenib in resisting metastasis of gastric cancer. Biomaterials 2014;35:4565-72.

9. Wang $\mathrm{XQ}$, Zhang $\mathrm{Q}$. pH-sensitive polymeric nanoparticles to improve oral bioavailability of peptide/protein drugs and poorly water-soluble drugs. Eur J Pharm Biopharm 2012;82:219-29.

10. Gajjar DG PR, Patel VA, Patel PK. Novel hydroxyl terminated dendrimers as potential drug carriers: sustained release, hemolysis and cytotoxicity study. Int J Appl Pharm 2015;7:5-9.
11. Carpenter MK. Design of oral sustain release drug delivery of quetiapine fumarate. J Drug Discovery Ther 2014;2:7-11.

12. Boateng J, Okeke O, Khan S. Polysaccharide based formulations for mucosal drug delivery: a review. Curr Pharm Des 2015;21:4798-821.

13. Pai GK, Reddy SM. Design, fabrication and evaluation of ss 316 punch die set for accurate sizing of sodium cromoglycate ocular inserts. Int J Pharm Pharm Sci 2014;6:244-7.

14. Rekha M, Sharma CP. Pullulan as a promising biomaterial for biomedical applications: a perspective. Trends Biomater Artif Organs 2007;20:116-21.

15. Prajapati VD, Jani GK, Khanda SM. Pullulan: an exopolysaccharide and its various applications. Carbohydr Polym 2013;95:540-9.

16. Singh RS, Kaur N, Kennedy JF. Pullulan and pullulan derivatives as promising biomolecules for drug and gene targeting. Carbohydr Polym 2015;123:190-207.

17. Dragojevic S, Ryu JS, Raucher D. Polymer-based prodrugs: improving tumor targeting and the solubility of small molecule drugs in cancer therapy. Molecules 2015;20:21750-69.

18. K Maurya A, Singh M, Dubey V, Srivastava S, Luqman S, U Bawankule D. $\alpha-(-)$-bisabolol reduces pro-inflammatory cytokine production and ameliorates skin inflammation. Curr Pharm Biotechnol 2014;15:173-81.

19. Wei JC, Qu K, Wang ZX, Wu QF, Zhang LQ, Pang Q, et al. Sorafenib inhibits proliferation and invasion of human hepatocellular carcinoma cells via up-regulation of p53 and suppressing FoxM1. Acta Pharmacol Sin 2015;36:241-51.

20. Surai PF. Silymarin as a natural antioxidant: an overview of the current evidence and perspectives. Antioxidants 2015;4:204-47.

21. Mishra S, Katare D. Synergistic combination for chemoprevention of hepatocellular carcinoma: an in-silico and in-vitro approach. Basic Clin Pharmacol Toxicol 2017;120:53240.

22. Gazak R, Walterova D, Kren V. Silybin and silymarin-new and emerging applications in medicine. Curr Med Chem 2007;14:315-38.

23. Tres F, Treacher K, Booth J, Hughes LP, Wren SA, Aylott JW, et al. Indomethacin-kollidon VA64 extrudates: a mechanistic study of pH-dependent controlled release. Mol Pharm 2016;13:1166-75.

24. Na K, Lee ES, Bae YH. Adriamycin loaded pullulan acetate/sulfonamide conjugate nanoparticles responding to tumor $\mathrm{pH}$ : $\mathrm{pH}$-dependent cell interaction, internalization and cytotoxicity in vitro. J Controlled Release 2003;87:3-13.

25. Gu HR, Park SC, Choi SJ, Lee JC, Kim YC, Han CJ, et al. Combined treatment with silibinin and either sorafenib or gefitinib enhances their growth-inhibiting effects in hepatocellular carcinoma cells. Clin Mol Hepatol 2015;21:49-59.

26. Shoichet BK, McGovern SL, Wei B, Irwin JJ. Lead discovery using molecular docking. Curr Opin Chem Biol 2002;6:439-46.

27. Mani RJ, Mittal K, Mishra S, Kharkwal H, Ahmad S, Katare DP. In silico approach to evaluate the efficacy of dietary flavonoids and their role in alzheimer's disease. Int J Pharm Sci Rev Res 2015;34:94-102.

28. Huang SMA, Mishina YM, Liu S, Cheung A, Stegmeier F, Michaud GA, et al. Tankyrase inhibition stabilizes axin and antagonizes Wnt signalling. Nature 2009;461:614-20.

29. Stamos JL, Weis WI. The $\beta$-catenin destruction complex. Cold Spring Harbor Perspect Biol 2013;5:a007898.

30. Li L, Zeng J, Gao Y, He D. Targeting silibinin in the antiproliferative pathway. Expert Opin Investig Drugs 2010;19:243-55.

31. Wilhelm SM, Carter C, Tang L, Wilkie D, McNabola A, Rong H, et al. BAY 43-9006 exhibits broad spectrum oral antitumor activity and targets the RAF/MEK/ERK pathway and receptor tyrosine kinases involved in tumor progression and angiogenesis. Cancer Res 2004;64:7099-109. 